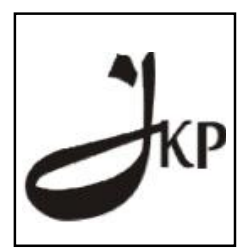

Jurnal Konseling dan Pendidikan

ISSN Cetak: 2337-6740 - ISSN Online: 2337-6880

http://jurnal.konselingindonesia.com

Volume 1 Nomor 1, Februari 2013, HIm 10-14

\title{
Perubahan Pola Pikir Basis Implementasi Kompetensi Konselor
}

\author{
Kusnarto Kurniawan ${ }^{1 *}$ \\ ${ }^{1}$ Fakultas Ilmu Pendidikan, Universitas Negeri Semarang
}

\begin{abstract}
Abstratc
Peraturan Menteri Pendidikan Nasional Republik Indonesia Nomor 27 Tahun 2008 tentang Standar Kualifikasi Akademik dan Kompetensi Konselor telah empat tahun digulirkan. Dalam kurun waktu empat tahun telah dilakukan berbagai kegiatan untuk melaksanakan peraturan ini oleh lembaga penjaminan mutu pendidikan, LPTK, Asosiasi Bimbingan dan Konseling Indonesia (ABKIN), serta Musyawarah Guru Bimbingan dan Konseling (MGBK). Kegiatan sosialisasi, seminar, lokakarya, workshop, talk show, serta pendidikan dan latihan dilakukan dengan melibatkan unsur akademisi, praktisi, organisasi profesi dan lembaga terkait yang muaranya pada impelementasi kompetensi konselor terutama konselor sekolah atau guru bimbingan dan konseling yang langsung diterapkan kepada siswa anak bangasa calon penerus generasi bangsa. Konselor sekolah atau guru bimbingan dan konseling sebagai pelaksana utama dan langsung seringkali menginginkan jalan pintas dan praktis atau instan untuk bisa berubah dan menguasai kompetensi, sulit keluar dari kebiasaan yang sudah dilaksanakan selama ini, tidak kuasa dan tidak berdaya untuk melakukan perubahan dirinya serta mengkomunikasikan di tempat kerjanya. Padahal dalam kompetensi kepribadian nomor 7 disebutkan menampilkan kinerja berkualitas tinggi, 7.1. menampilkan tindakan yang cerdas, kreatif, inovatif, dan produktif. Untuk bisa menampilkan tindakan yang cerdas, kreatif, inovatif, dan produktif basisnya adalah perubahan pola pikir konselor. Perubahan dari menghafal teori kompetensi dengan kepala diganti dengan hati, sekedar mengikuti pelatihan menjadi terlibat dalam pelatihan, budaya instan menjadi pembelajar serta berani berpikir bebas dan kreatif atau out of the box.
\end{abstract}

Keyword: pola pikir, kompetensi konselor, budaya instan, berpiikir bebas dan kreatif

Copyright (C 2013 IICE - Multikarya Kons - All Rights Reserved Indonesian Institute for Counseling and Education (IICE) Multikarya Kons

\footnotetext{
${ }^{*}$ Telp dan/atau Alamat Email Koresponden :

1. E-mail address : kusnarto@yahoo.co.id
} 


\section{PENDAHULUAN}

Harian Suara Merdeka 19 Oktober 2012 memberitakan berdasarkan informasi Kepala Badan Pengembangan Sumber Daya Manusia Pendidikan dan Penjaminan Mutu Pendidikan (BPSDMPPMP) hasil sementara analisis dan pemetaan Uji Kompetensi Guru (UKG) gelombang pertama sekitar 49\% di bawah rata-rata. Sebagai tindak lanjut untuk peningkatan kompetensi guru, BPSDMPPMP akan menyelenggarakan pendidikan dan latihan online terbimbing dengan memanfaatkan tempat uji kompetensi (TUK). Bagi guru yang berada di daerah atau lokasinya belum tersambung dengan jaringan akan diberi pendidikan dan latihan interaktif dengan diberi VCD yang didalamnya berisi metode pembelajaran dan evaluasi. Sementara informasi langsung mapun melalui sms dari teman-teman Pengurus Cabang Asosiasi Bimbingan dan Konseling Indonesia dan Musyawarah Guru Bimbingan dan Konseling (MGBK) di Jawa Tengah rata-rata setiap tempat uji kompetensi (TUK) lulus satu atau dua orang guru bimbingan dan konseling. Mereka yang lulus memperoleh nilai antara 71-79 dari standar kelulusan yang ditetapkan yaitu 70. Uji Kompetensi Guru Bimbingan dan Konseling dikembangkan dari Peraturan Menteri Pendidikan Nasional RI Nomor 27 Tahun 2008 tentang Standar Kualifikasi Akademik dan Kompetensi Konselor terutama pada kompetensi pedagogik dan kompetensi profesional. Guru Bimbingan dan Konseling yang diuji adalah yang sudah memperoleh sertifikat pendidik sebagai guru bimbingan dan konseling profesional karena mereka telah memperoleh tunjangan profesi. Logikanya guru bimbingan dan konseling yang sudah memperoleh tunjangan profesi harusnya profesional artinya mempunyai seperangkat wawasan, pengetahuan, keterampilan, nilai dan sikap tentang bimbingan dan konseling yang mempribadi serta diamalkan dalam praktik nyata sehari-hari.

Melihat fenomena yang terjadi pertanyaan yang muncul apa yang salah? Guru bimbingan dan konseling yang sudah memperoleh sertifikat pendidik yang belum profesional? Soal uji kompetensi guru bimbingan dan konseling yang tidak tepat untuk mengukur? Ketidak siapan mental guru bimbingan dan konseling menghadapi uji kompetensi? Dan masih banyak pertanyaan lain yang muncul. Sulit untuk menentukan faktor penyebab utama apa sehingga guru bimbingan dan konseling banyak yang tidak lulus dan yang lulus uji komptensi memperoleh nilai antara 71-79 di Jawa Tengah (data sementara gelombang pertama dan gelombang dua yang sedang berjalan). Dari sisi guru bimbingan dan konseling variasinya juga beragam. Guru bimbingan dan konseling yang lulusan S1 BK dan sudah lama (senior) menjadi guru BK. Ada guru BK yang bukan berasal dari S1 BK tapi alih fungsi dari guru mata pelajaran. Ada pula guru BK yang baru antara 5-10 tahun menjadi guru BK dan berasal dari S1 BK serta guru BK yang baru antara 5-10 tahun menjadi guru BK dan berasal dari non S1 BK. Kenyataannya kalau sudah tersertifikasi sebagai guru BK tentu akan masuk sebagai komunitas guru BK profesional yang mengikuti uji kompetensi guru bk tanpa melihat asala dan variasinya. Dengan demikian merekalah tanggungjawab dan komunitas kita yang menjadi wilayah pengembangan profesi kita demi kejayaan profesi BK. Uraian berikut menyorot dari sisi guru bimbingan dan konseling berdasarkan pengalaman pribadi ketika memberikan pendidikan dan latihan profesi guru (PLPG), bimbingan teknis dan peningkatan kompetensi guru bimbingan dan konseling yang diselenggarakan oleh Lembaga Penjaminan Mutu Pendidikan (LPMP) Jawa Tengah.

\section{PEMBAHASAN}

\section{Kompetensi Konselor}

Dari 17 kompetensi inti konselor yang tertuang dalam Peraturan Menteri Pendidikan Nasional RI Nomor 27 Tahun 2008 tentang Standar Kualifikasi Akademik dan Kompetensi Konselor, saya soroti kompetensi kepribadian nomor 7 yang berbunyi menampilkan kinerja berkualitas tinggi, 7.1.yang menyatakan menampilkan tindakan yang cerdas, kreatif, inovatif, dan produktif. Menampilkan kinerja berkualitas tinggi sesungguhnya jawaban dan jaminan terhadap mis konsepsi terhadap guru BK selama ini diantaranya sebagai polisi sekolah, hanya menanganani anak yang bermasalah dan nakal serta guru BK banyak memberikan nasehat. Bagaima $\neg$ nakah tindakan yang cerdas? Prayitno dan Khaidir (2011:18) mengemukakan cerminan perilaku dan indikator individu yang memliki kecerdasan adalah aktif, dinamis dan terarah, analisis dan objektif, kreatif dan inovatif, antisipatif, berpikiran terbuka dan maju, serta mencari solusi. Dari pendapat tersebut apabila diimplementasikan dalam ranah bimbingan dan konseling maka guru bimbingan dan konseling dalam memberikan layanan konseling di sekolah tentu akan menjadi guru bimb $\neg$ ingan dan konseling di sekolah yang mantap, disenangi dan dibutuhkan utamanya oleh siswa, guru lain, kepala sekolah dan wakil kepala sekolah serta orang tua dan masyarakat pada umumnya.

Guru bimbingan dan konseling yang aktif maknanya luas sekali. Aktif mencari informasi untuk peningkatan kualitas diri dan mutu layanan. Aktif dalam kegiatan MGBK, Organisasi Profesi, dan kegiatan-kegiatan ilmiah untuk pengembangan profesi. Dinamis dan terarah kondisi fisik untuk memberikan pelayanan yang optimal, kondisi mental bergerak kearah pencapaian tujuan bimbingan dan konseling yaitu membantu individu mencapai perkembangan yang optimal, membantu individu mencapai $\neg$, serta mengantarkan individu mencapai kebahagiaan. Analisis dan objektif dalam setiap tindakan, setiap perencanaan, pelaksanaan, serta evaluasi layanan dan program bimbingan dan konseling. Kreatif dan inovatif, untuk benarbenar menciptakan sesuatu yang baru sampai dipatenkan memang tidak semua orang mempunyai peluang, kesempatan dan kemauan serta kemampuan yang seperti itu, Akan tetapi untuk melakukan inovasi hampir semua orang mampu melakukan asal ada kemauan. Tidak hanya bisa menilai dan mengkritik tapi memberikan pembaharuan, memodifikasi dan menjadikan lain dari yang sudah tentu dalam memberikan layanan bimbingan dan konseling. Antisipatif contoh nyata kegiatan guru bimbingan dan 
konseling yang bisa dilakukan adalah menyiapkan secara mental siswa menghadapi ujian akhir semester ataupun ujian akhir nasional melalui jenis layanan yang menarik dan menantang siswa. Dengan layanan yang antisipatif dan dilakukan guru bimbingan dan konseling maka kepala sekolah dan guru lain akan yakin denganh kinerja guru bimbingan dan konseling sehingga menghadapi ujian akhir nasional tidak perlu meng $\neg$ undang jasa atau biro lain untuk melakukan pengkondisian mental siswa. Berpikiran terbuka dan maju bagi guru bimbingan dan konseling juga harus selalu dikembangkan supaya pelaksa $\neg$ naan asas keterbukaan juga makin mantap. Disamping itu guru bimbingan dan konseling akan selalu ingin mendap $\neg$ atkan sesuatu yang baru, berkembang, dan berkualitas dalam setiap memberikan pelayanan konseling. Mencari solusi setiap ada permasalahan terkait dengan pelayanan yang diberikan, hambatan dan tantangan yang dihadapi maka guru bimbingan dan konseling tidak pasrah, masa bodoh, menyalahkan pihak lain tetap aktif mencari jalan keluar supaya kembali efektif dalam memberikan pelayanan bimbingan dan konseling. Figur guru bimbingan yang mempunyai kecerdasan seperti diuraikan di atas, inilah yang akan menampilkan kinerja berkualitas tinggi. Dengan kinerja yang berkualitas tinggi maka guru bimbingan dan konseling tidak akan dianggap dan dipersepsikan keliru misaln $\neg$ ya dalam menghadapi tawuran pelajar dianggap tidak bekerja atau dipertanyakan kinerjanya termasuk oleh psikolog. Komentar hal ini oleh Psikolog Tika Bisono dapat dilihat di okezone.com (Rabu 10 Oktober 2012).

\section{Budaya Instan}

Istilah budaya sebenarnya tidak tepat dalam arti budaya sebagai hasil budi daya manusia. Dalam konteks ini adalah kebiasaan instan atau maunya cepat tanpa harus bersusah payah tetapi memperoleh hasil yang maksimal. Pengalaman pribadi ketika memberikan pendidikan dan latihan profesi guru (PLPG), bimbingan teknis dan peningka $\neg$ tan kompetensi guru bimbingan dan konseling yang diselenggarakan oleh Lembaga Penjaminan Mutu Pendidikan (LPMP) Jawa Tengah serta mengisi pada kegiata musyawarah guru bimbingan dan konseling (MGBK), hampir 80\% guru bimbingan dan konseling menunjukkan sikap inginnya cepat berhasil, menguasai materi tetapi tidak mau bersusah payah. Perilaku yang sangat nampak misalnya bertanya adakah file nya untuk dicopy? Menunjuk teman lain tidak menhajukan dirinya ketika harus menjadi model. Men $\neg$ anyakan contoh atau model yang sudah ada dan masih banyak lagi perilaku lainnya. Contoh nayat sebelum menyusun program didahului dengan melakukan identifikasi kebutuhan dan permasalahan siswa. Hasil identifikasi kebutuhan dan permasalahan dibuat dalam matriks untuk memetakan penyeb $\neg$ aran kegiatan dalam semester, bulan, minggu, sampai harian. Barulah disusun program. Kenayataan banyak yang memilih menggunakan identifikasi kebutuhan dan masalah siswa (IKMS) yang dikembangkan Andori dkk karena ini lebih instan sekali menentry data samapai satuan layanan sudah jadi tanpa harus bersusah payah dan berepot-repot. Padahal dalam pelayanan bimbingan dan konseling intepretasi dari guru bimbingan dan konseling berdasarkan data yang diperoleh masih diperlukan. Contoh sikap mental yang demikian mencerminkan perilaku yang bertentangan dengan pepatah berakit-rakit ke hulu berenang renang ketepian. Mengingkari prinsip belajar sepanjang hayat.

Hal mendasar yang perlu diubah adalah bagaimana guru bimbingan dan konseling mau menjadi teladan dengan menjadi pembelajar yang handal. Selalu mengasah, memperbarui, dan mener $\neg$ apkan hal-hal yang baru diperolehnya baik belajar sendiri maupun mengikuti pelatihan. Ketika mengikuti pelatihan tidak sekedar datang untuk memenuhi tugas tetapi benar-benar aktif terlibat dalam proses pelatihan. Kegagalan dari pendidikan dan latihan pada umumnya, bimbingan teknis, serta diklat peningkatan kompetensi selama ini karena secara umum mereka setalah mengikuti pelatihan satu minggu setelah pulang ke satuan masing-masing mereka terlihat perbedaan sikap mereka terutama rasa percaya diri dan sikap antusiasmenya. Satu bulan berikutnya tinggal satu sampai lima orang yang masih terlihat antusias menerapkan ilmu yang diperoleh dari pelatihan. Tiga bulan atau enam bulan kemudian mereka sudah tidak terdengar lagi bagai ditelan bumi. Mereka kembali kepada model pelayanan lama ketika sebelum mengik $\neg$ uti pelatihan. Kelemahan dari model pelatihan ini salah satunya menurut saya karena pasca pelatihan belum dilakukan monitoring dan evaluasi yang terencana disamping dari sisi individu guru bimbingan dan konseling juga masih terbawa kebiasaan instan ingin cepat berubah, berhasil, dan memperoleh hasil yang maksimal tanpa usaha dan kerja keras.

\section{Melakukan dengan Hati}

Agustian (2004:xlvii) memaparkan untuk mencapai keberhasilan melakukan sesuatu bukan menghafal teori dengan kepala tetapi melakukan dengan hati dan berlatih sehingga menjadi kebiasaan yang mengkarakter dan menginternal dalamn diri. Menyimak pernyataan Agustian tersebut jadi teringat kegagalan CBSA yang diplesetkan menjadi cah bodho saya akeh atau anak bodoh makin banyak merupakan sikap pesimis dan bentuk kegagalan dari CBSA karena menghafal teori, maka yang terjadi di sekolah-sekolah terutama SD setting duduk melingkar atau duduk persegi dengan menggunakan diskusi tanpa dengan isi dan hati dianggap sudah tepat dan mengharapkan hasil yang maksimal. Dalam konteks implementasi guru bimbingan dan konseling di sekolah sering dijumpai orang tersebut menguasasi teori dan pendeketan konseling tapi kering dan miskin dalam praktiknya. Transkrip nilainya mungkin sangat memuaskan bahkan dengan pujian tetapi praktiknya di sekolah tidak mencerminkan nilai yang diperoleh. Hal ini karena mereka kurang berlatih, belum menginternal teori dan konsep yang dimiliki, dan melakukannya tidak dengan hati. 
Prayitno dan Khaidir (2011:93) mengemukakan proses pembelajaran yang memungkinkan terjadinya pem $\neg$ berian balikan dan penguatan melalui proses berpikir, merasa, bersikap, bertindak, dan bertanggungjawab (BMB $\neg 3$ ). Implementasi dalam pelayanan konseling, guru bimbingan dan konseling yang bisa melakukan proses konseling dengan BMB3 tentu melakukan proses layanan konseling dengan hati tidak hanya menghafal teori dengan kepala. Guru bimbingan dan konseling yang bisa menerapkan BMB3 dalam pemberian layanan tentu sudah menguasai teori dan pendekatan juga menerapkan makna konseling sebagai seni. Apabila guru bimbingan dan konseling menerapkan BMB3 maka secara nyata sudah memulai untuk menampilkan kinerja yang berkualitas tinggi.

\section{Berpikir Bebas dan Kreatif}

Berani berpikir bebas dan kreatif atau out of the box merupakan hal mendasar yang harus dikembangkan oleh guru bimbingan dan konseling. Masih sering dijumpai pertanyaan yang muncul dari peserta diklat, bintek, diklat peningkatan kompetensi maupun kegiatan di MGBK terhadap suatu kegiatan atau penugasan pertanyaan yang muncul adalah yang standar atau yang baku seperti apa? Pertanyaan seperti ini menunjukkan guru bimbingan dan konseling sebagian besar masih terkungkung dalam paradigma menunggu petunjuk pelaksanaan dan petunjuk teknis kegiatan. Padahal dalam bimbingan dan konseling keunikan tugas dan ekspektasi kerjanya jelas berbeda dengan guru mata pelajaran maupun guru muatan lokal. Mulai dari melakukan identifikasi kebutuhan dan $\neg$, pemahaman konseli secara mendalam, sampai kepada penyusunan program dan pelaksa $\neg$ naan atau pemberian layanan sebagai aksi nyata guru bimbingan dan konseling menuntut untuk berpikir bebas dan kreatif supaya layanan menjadi bermakna, kontekstual dan tidak kering. Salah satu contoh adalah tawuran pelajar yang marak terjadi akhir-akhir ini, pemberitaan tentang terorisme, perseteruan antara KPK dan Polisi, semua peristiwa tersebut ada urgensinya dan relevansinya dengan perkembangan individu tentu merupakan bahan untuk muatan layanan yang lebih menarik, antisipatif dan bermakna serta mengembangkan wawasan, pengeta $\neg$ huan, keterampilan, nilai dan sikap peserta didik. Dengan mengaitkan materi/topik sesuai dengan kejadian nyata perolehan peserta didik menjadi komplit. Hanya guru bimbingan dan konseling yang berpikir bebas dan kreati $\neg$ flah yang mampu dan berani melakukan kegiatan yang kontekstual dan antisipatif.

Dalam kegiatan MGBK akan lebih dinamis dan tidak sekedar memenuhi jadwal serta kewajiban guru bimbingan dan konseling apabila didalamnya berisi diskusi profesional yang substansinya perwujudan dari berani berpikir bebas dan kreatif. Bebas bukan berarti tanpa batas. Batas-batasnya jelas standar prosedur operasional, norma-norma yang berlaku dan kaidah keilmuan. Kretaif tidak harus menciptakan yang baru tetapi memodifikasi, mengim $\neg$ provisasi atau melengkapi juga sudah bagus, apalagi bisa menciptakan model yang baru. Keberanian dan kemauan untuk memulai agaknya merupakan hal yang harus dikuatkan. Karena umunya guru bimbingan dan konseling kurang suka menjadi yang pertama atau contoh. Umumnya mereka melihat dulu kalau ada yang memulai atau menjadi yang pertama baru setelah ada bukti, diakaui orang lain beramairamai mengikuti. Pola pikir yang demikian harus diubah. Guru bimbingan dan konseling harus ada kemauan dan berani untuk memulai, berami menjadi yang pertama, karena hal inilah keteladanan yang dapat ditularkan kepada peserta didik.

\section{Perubahan Pola Pikir}

Schwartz (1996:170) menyatakan cara berpikir seseorang menentukan bagaimana ia bertindak. Cara seseorang bertindak menentukan bagaimana orang lain berekasi terhadap tindakannya. Relevansinya dengan guru bimbingan dan konseling yang selama ini merasa terpinggirkan, tidak dianggap dan dipandang sebelah mata kontribusinya dalam pencapaian prestasi siswa di sekolah, tidak berdaya menyuarakan dengan kolega lain dan pihak sekolah harus mengubah pola pikirnya. Bim $\neg$ bingan dan konseling merupakan hal yang sangat penting dalam membawa keberhasilan siswanya. Pola pikir seperti ini yang harus dijadikan mimpi yang realistis dan diwujudkan dalam tindakan nyata oleh guru bimbingan dan konseling di sekolah. Pelayanan bimbingan dan konseling yang menjadi penting, dibutuhkan, dicintai, dan dinanti-nantikan kehadirannya oleh siswa, kolega di sekolah, kepala sekolah, wakil kepala sekolah serta orang tua atau masyarakat hanya bisa diwujudkan dengan kinerja yang berkualitas tinggi. Guru bimbingan dan konseling bisa menunjukkan kinerja yang berkualitas tinggi karena guru bimbingan dan konseling yang kompeten tentu saja profesional dan melakukan dengan hati. Guru bimbingan dan konseling yang mampu berpikir bebas dan berindak kreatif atau out of the box. Mengembalikan posisi bimbingan dan konseling menjadi sejajar mata pelajaran dan muatan lokal sebagaimana dalam komponen kurikulum 2004 diawalai dari perubahan pola pikir guru bimbingan dan konseling. Guru bimbingan dan konseling yang tidak memandang dirinya ban pelengakap/serep, kontribusinya tidak jelas bagi pencapaian prestasi peserta didik serta guru bimbingan dan konseling yang tahu tugas utama dan wilayah kerjanya. Inilah basis bagi penguasaan kompetensi guru bimbingan dan konseling atau konselor supaya dipandang dan diakui sejajar dengan guru mata pelajaran dan guru muatan lokal. Hal-hal seperti ini yang harus selalu ada pada pikiran guru bimbingan dan konseling serta berusaha mewujudkan sedikit demi sedikit, terus menerus dan pasti.

Lebih lanjut Schwartz (1996:262) menyarankan berpikir benar tentang orang lain. Sering kita mengeluh dengan situasi, kondisi dan keadaan yang kita hadapi. Maka saatnya untuk mengolah dengan rasa dan hati secara rasional. Orang lain boleh menilai dan $\neg$ kita seperti cara mereka menilai kita. Yang terpenting adalah selalu melakukan yang sesuai prinsip pelaksanaan dengan menginovasi sesuai kebutuhan dan lingkungan. Berpikir masih hijau untuk selalu belajar dan berkembang jauh lebih bijaksana dan membawa kemajuan, jika dibandingkan dengan berpikir sudah matang karena kalau berpikirnya kita sudah 
matang maka tunggu saatnya menjadi busuk. Jadikan hambatan dan tantangan kita untuk berpikir maju, bukan menjadi kita makin terpuruk dan tidak berbuat apa-apa. Perubahan pola pikir dari menunggu menjadi penginspirasi, menerima menjadi memberi. Memantapkan motivasi altruistik dalam memberikan pelayanan sehingga yang kita lakukan bukan karena pamrih tertentu akan tetapi yang kita lakukan untuk kepentingan dan kebahagiaan klien. Perubahan pola pikir yang demikian tentu akan mendorong guru bimbingan dan konseling untuk menjadi pembelajar, menguasai dan mengim $\neg$ plementasikan standar kompetensi yang dipersyaratakan sebagai konselor sebagai konsekuensi dari tunjangan profesi yang sudah dinikmati.

\section{PENUTUP}

Tulisan ini tidak bermaksud memojok $\neg$ kan guru bimbingan dan konseling atau tidak menghargai guru bimbinga $\neg$ n dan konseling yang sudah berkeja seoptimal mungkin memberikan pelayanan terbaik untuk peserta didik. Uraian di atas didasarkan pada pengalaman pribadi ketika memberikan pelatihan di PLPG, bintek, diklat peningkatan kompetensi maupun kegiatan MGBK. Harapannya dengan kita melihat dan menyadari masih dijumpai sikap mental guru bimbingan dan konseling yang demikian padahal standar kualifikasi dan akademik sudah empat tahun digulirkan makin mendorong kita untuk berani dan mau melakukan perubahan dan meningka $\neg$ tkan kompetensi. Selalu meningkatkan kompetensi sebagai konsekuensi sebagai guru bimbingan dan konseling profesional yang sudah mendapatkan tunjangan profesi. Perubahan pola pikir menjadi basisi untuk penguasaan komp $\neg$ etensi sehingga implementasi menjadi nyata. Dengan implementasi yang mencerminkan tindakan profesioanl maqka reaksi dari kolega, kepala sekolah, wakil kepala sekolah, orang tua atau masyarakat dan utamanya siswa menjadi benar terhadap pelayanan Bk. Dengan penilaian dan persepsi yang benar maka guru bimbingan dan konseling menjadi idola dan dinanti-nantikan serta dirindukan kehadirannya.

Dengan basisi perubahan pola pikir guru bimbingan dan konseling harapan $\neg$ nya kegiatan MGBK menjadi dinamis dan bermakana, ABKIN semakin eksis, para konselor alumni PPK menjadi berkontribusi langsung dalam penguatan peningkatan kompetensi guru bimbingan dan konseling serta dinas pendidikan atau kementrian pendidikan dan kebud $\neg$ ayaan, PPPPTK Penjas-BK, BPS $\neg$ DMPPMP, maupun LPMP semakin .

memprioritaskan guru bimbingan dan konseling. Diklat, bintek, maupun diklat peningkatan kompetensi guru bimbingan dan konseling tidak akan berarti apa-apa kalau tidak direncanakan dan dilaksan $\neg$ akan secara komprehensif disertai dengan monitoring evaluasi yang benar. Maka yang terjadai pasca diklat hanya bertahan satu minggu ada perubahan kepercayaan dan atusiasme yang tinggi. Lebih dari satu minggu perlahan-lahan akan kembali ke pola lama.

\section{DAFTAR PUSTAKA}

Agustian Ginanjar A, (2004), Rahasia Sukses Membangun Kecerdasan Emosi dan Spiritual: ESQ (Emotional Spiritual Quotient), Jakarta: Penerbit Arga

Harian Suara Merdeka, edisi Tahun 6 No.246 Jumat Legi, 19 Oktober 2012, Guru di Bawah Rata-Rata Akan Diklat Tatap Muka, halaman 9.

Prayitno dan Afriva Khaidir, (2011), Model Pendidikan Karakter Cerdas, Padang: UNP Press

Schwartz JD, (1996) alih bahasa Budiyanto FX, The Magic of Thinking Big (Berpikir dan Berjiwa Besar), Jakarta: Binarupa Aksara

BSNP, (2008), Peraturan Menteri Pendidikan Nasional Republik Indonesia Nomor 27 Tahun 2008 Tentang Standar Kualifikasi Akademik dan Kompetensi Konselor, Jakarta: Badan Standar Nasional Pendidikan. 